\title{
Potential Repetition in Tembang Dolanan In Javanese Language
}

\author{
Dyah Padmaningsih $^{1}$, Yohanes Suwanto ${ }^{2}$, Sri Supiyarno ${ }^{3}$, Endang Tri Winarni ${ }^{4}$ \\ \{dyahpadmaningsih@yahoo.co.id\} \\ Sebelas Maret University
}

\begin{abstract}
Repetition is a form of repeating a sound, syllable, word, or part of a sentence that is considered important to provide indexing and stress in a context that is in accordance with the meaning contained in that context. The problem of the study was repetition in the form of words, phrases, and clauses in tembang. The potential repetition contained in the Javanese language tembang dolanan or dolanan song greatly influences the uniqueness and beauty of the tembang. The data were in the form of song lyrics, including words, phrases, clauses, and sentences used in the tembang. An interactive analysis method with respondents was employed in this study. Repetition such as Epizeuxis, Taautoles, Epanolepsis, Mesodiplosis, and Anadiplasis were found in this study.
\end{abstract}

Keywords: repetitive structure, tembang dolanan, Javanese language

\section{Introduction}

Tembang dolanan is one of the traditional literary works that is conveyed orally. In general, this song is liked by children, because of its nature as entertainment and easy to follow. Dolanan is a song that is sung by children, whether accompanied by musical accompaniment, movement/dance or not, whose lyrics are adapted to the development of the child's mind and the child's imagination [1]. Tembang can be defined as Javanese poetry that is sung both with tone and rhythm [2]. Dolanan comes from the word dolan, which means to play and get the -an suffix. This song is spread orally to be classified as folklore. Folklore is a collective tradition of a nation that is spread in oral and sign forms. Thus, it remains sustainable from generation to generation [3].

The use of language in traditional Javanese songs takes advantage of the potential of language which is manifested in song lyrics. The use of repetition, the figure of speech, is distinctive to create an aesthetic, dynamic, and expressive literary discourse. Repetition is different from reduplication. Repetition is the repetition of sounds in the forms of phonemes, syllables, phrases, clauses, and sentences. The stress is the same for each one that is repeated, without a hyphen between two repeated words, which generally means affirmation. In this study, repetition was discussed in the form of words, phrases, and clauses. The authors used repetition to make their songs clearer, aesthetically pleasing, and bring out a beautiful rhythmic harmony that is easy to remember. Reduplication of word formation through the repetition process, which is marked with a hyphen, the combined result in the form of two words is applied to one word, has meaning under the repeated form, and the emphasis is on the second word.

In general, tembang dolanan contains moral and social teachings that are tailored to the development of the child's mind. Tembang dolanan is artistic literature that is good for 
processing pleasant sounds and as a venue for artistic creativity and the human mind. This traditional tembang dolanan is free of rules and is not bound by the guru lagu (vowels at the end of each line), guru wilangan (the number of syllables in each line), and guru gatra (the number of lines in each stanza). The language used is simple, indicating that it is easy to understand and memorized [4].

This study only discussed the form of repetition and the meaning of its special culture of repetition in the form of words, phrases, and clauses. The form refers to the repetition makers. Therefore, they can classify the types of repetition. Meanwhile, the cultural meaning is in the form of invitations, intentions, ideas, people's thinking patterns, and the authors' message which is poured into the tembang dolanan adapted to the conditions of the Javanese society. In the end, it might find the meaning of the teachings in the tembang dolanan.

\section{Research Methods}

A descriptive qualitative method was employed in this study, where the research procedure produced descriptive data in the form of words or writings. Qualitative research is a study aimed at describing and analyzing phenomena, events, social activities, attitudes, beliefs, perceptions, thoughts of people individually or in groups [5]. A procedure or process is needed starting from planning, implementing, and reporting the results of the study to solve the problem in order not to get confused [6].

Sources of data came from informants with specified criteria. The data of this study were in the form of Javanese words, phrases, and sentences used in the Javanese song lyric of the tembang dolanan. Since the data were in the form of qualitative data, data collection was explored utilizing interviews. It is expected that the researchers got as much data as possible from resource persons or informants. Data collection was carried out periodically from oral data sources in the form of active activities to the research location by interview. The interview was conducted to obtain information or views orally, which directly or indirectly know and participate in communication when speech events occur. Therefore, the implementation of the interview used an unstructured interview technique [7].

Data analysis was carried out after the collected data were classified based on their type and analyzed using an analytical descriptive approach, which describes the data that has been collected and analyzes it. Analyzing means breaking down or sorting out the elements that make up the lingual unit or breaking down a lingual unit into its components or containing the meaning of determining the identity of a lingual unit. Determination of identity is based on instructions from a frame of mind or based on testing based on certain aspects of a lingual that were studied [8]. Data analysis was also carried out interactively involving three components, namely data reduction, data presentation, and concluding [9].

This analysis was intended to reveal the morphological process and the meaning of word formation in the tembang dolanan. Literature is the crystallization of beliefs, values and norms that become consensus in the society [10]. Interactive analysis is the interaction of three main components which include data reduction, data presentation, and drawing conclusions and verification [11]. 


\section{Results and Discussion}

Repetition is the repetition of sounds, syllables, words, or parts of sentences that are considered important to emphasize in an appropriate context. This study only analyzed repetitions in the form of words, phrases, or parts of sentences. The repetitions found were:

a. Epizeuxis is direct repetition, indicating that the emphasized word is repeated several times in a row.

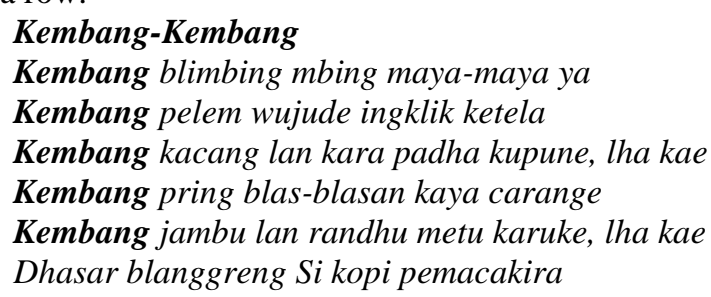

Dolanan song entitled kembang contains repetition. The word kembang is repeated five times in one song and the repetition of the word kembang is always at the beginning of the line. Repetition of words in the song Kembang-kembang includes epizeuxis repetitions. The repetition serves to clarify the song that the name of the flowering plant has a different name. The repetition of the word kembang (flower) is a basic form, which cannot be minimized, has a fixed meaning, and categorized as a noun. The author intends to explain the name 'flower' of a plant that can easily grow around a home page. This repetition function confirms and clarifies meanings and shows the harmony of the lyrics in the tembang.

a. Tautoles is the repetition of a word over and over in a construction.

\section{Padang Bulan}

Yo, para kanca dolanan ning jaba

Padang mbulan, padange kaya rina

Rembulane sing ngawe-awe

Ngelingake aja pada turu sore

In the sone entitled Padang Bulan, there are repetitions of tautoles, a repetition of the word in one construction. The word padang (bright) which is found at the beginning, is repeated on the next line of the word padange with the addition of $\boldsymbol{e} \boldsymbol{e}$ suffix. The author wants to emphasize the state of nature by repeating the word padang which is synonymous with rina (very clear). In this song, the author fosters a sense of love for God.

Thus, humans are always grateful for His creation which has given pleasure to nature and its surroundings. Furthermore, this song encourages us to make good use of time and always performs worship and teaches love by keeping in touch with others and avising not to sleep early. This song shows the great mercy of Allah for His people. Hence, people are obliged to be grateful for His greatness and the grace that He gives. The religious identity is seen through clothing, the language used, and the hairstyle [12].

b. Epistrophe is a repetition of a word or phrase at the end of a line.

Gundhul-gundhul Pacul

Gundhul-gundhul Pacul-cul gemblelengan

Nyungi-nyunggi wakul-kul gemblelengan 


\title{
Wakul glimpang segane dadi saratan
}

Wakul glimpang segane dadi saratan

Tembang or song called Gundhul Gundhul Pacul contains an epistrophe repetition in the form of a word, namely gemblelengan which is found at the end of the first line repeated at the end of the next line. Likewise, the Wakul glimpang segane dadi saratan is fully repeated in the next line. This repetition aims to clarify the meaning of the song or tembang and establish rhythmic harmony.

The meaning contained in this song is a suggestion not to boast both during success and in adversity. Be careful in living life to be prioritized. Thus, do not fall into things that are detrimental to oneself. Wakul glimpang segane dadi saratan describes the fortune that has been accumulated so much. If it is not properly maintained, it will spill or disappear everywhere due to negligence. The verses of the song describe the nature of being careful, disciplined, conscientious, tolerant, humble in society, and not being careless. Therefore, human always has to be grateful to God Almighty who has made it easier to find a fortune to be well cared for. Someone also needs to stay away from arrogant nature.

d. Mesodiplosis is the repetition in the middle of lines or sentences.

Lamun golek, wong lanang ja nganggo menek

Lamun menek. Wong lanang ja nganti mencit

Lamun mencit, Wong lanang ja nganti tiba

Lamun tiba, Wong lanang ja nganti lara

The song stated above contains Mesodiplosis repetitions, where the repetition is found in the middle of each sentence in the form of a phrase. Furthermore, there is anadiplosis repetition, that is, the word at the end of the line is repeated on the next line. The word menek at the end of the first line is repeated on the second row. The word mencit in the second row is repeated in the third row and the word tiba at the end of the third row is repeated on the fourth row. The function of this repetition is an affirmation of meaning.

The author reminds men in earning a living not to be overly ambitious. Thus, they will not be disappointed if they cannot get what they want. This commemoration aims to provide motivation to enable us to always remember and give thanks to God who has given us pleasure. However, this pleasure is obtained with honesty, diligence, and enthusiasm as well as sincerity with all that can be obtained and not to be boasted.

e. Anadiplosis is the last word or phrase from a clause or sentence that becomes the first word or phrase of the next clause or sentence. For example:

\author{
SUWE ORA JAMU \\ Suwe ora jamu \\ Jamu godhong tela \\ Suwe ora ketemu \\ Ketemu pisan gawe gela \\ Suwe ora jamu \\ Jamu godhong keningkir \\ Suwe ora ketemu \\ Ketemu pisan dadi pikir
}




\section{DOLANAN DOMINO}

Domino idomino babu ngendong sinyo...

Sinyone nangis wae didolani motor mabur..

Montor mabur kapal udara numpak sepur mudun Jakarta..

Jakarta akeh copete sopir becak akeh duite..

Duite mung selawe lambe ndomble njalok dijotosi

The tembang called Suwe Ora Jamu contains a repetition of Anadiplosis, which is the last word or phrase from a clause or sentnce to become the first word or phrase of the next clause or sentence. The word jamu which is located at the end of the first and fifth lines is repeated at the beginning of the second and sixth lines. Likewise, the word ketemu which is located at the end of the third and seventh lines is repeated at the beginning of the fourth and eighth lines.

Tembang Dolanan Domino takes advantage of Anadiplasis reps by repeating the word at the end of the line, repeated at the beginning of the next line. The word sinyo at the end of the first line is repeated at the beginning of the second line. The motor mabor phrase located at the end of the third line is also repeated in the same form at the beginning of the fourth line. The word Jakarta which is located at the end of the fourth line is repeated at the beginning of the fifth line. Meanwhile, the word duit at the end of the fourth line is repeated at the beginning of the fifth line. These repetitions are to beautify the song and emphasize meaning.

The author's message through the song or tembang entitled Suwe Ora Jamu is a meeting that strengthens the friendship of a long-established and separated friendship. Friendship will be maintained if one another respects each other, humble, respectful, willing to help, and tolerant. Even though the situation and circumstances are different, a common commitment can be maintained.

The song Domino describes the sound of entertainment, attitude, and responsibility, as well as the hard work depicted in the fourth and fifth lines of the line to maintain how much fortune has been earned. Djajasudarma suggests that the value system is so pervasive and rooted in the soul of the community that it is difficult to replace or change in a short time [13].

\section{Conclusion}

From the results and discussion above, the following conclusions can be drawn: (1) Tembang dolanan is part of Javanese poetry that is free in the choice of words but still maintains politeness in a form of folklore, which is conveyed orally and is a product of a local culture that still exist nowadays; (2) One of the peculiarities in tembang dolanan is the choice of words by utilizing the form of repetition which has the function of emphasis, harmony, and supports the aesthetics of the song lyrics and the beauty of singing the tembang more harmoniously; (3) The message in the sing describes the daily life of humans in society such as religious characteristics, discipline, tolerance, cooperation, togetherness, mutual respect, respect, and harmony in life; (4) The tembang dolanan (dolanan song in childrens' games) needs to be preserved and developed because it is loaded with good moral messages and is still relevant nowadays.

\section{References}

[1] Supanto, dkk (tim). 1981/1982. Sejarah dan Budaya (Seri: Folklore). Yogyakarta: Balai Penelitian Sejarah dan Budaya

[2] Nurgiyantoro, B. 2005. Sastra Anak, Pengantar Pemahaman Dunia Anak. Yogyakarta: Gadjah Mada University Press 
[3] Danandjaja, James. 1984. Folklor Indonesia : Ilmu Gosip, Idongeng, dan lain-lain. Jakarta: Grafiti Pers.

[4] Padmanngsih, Dyah. 2013. Kearifan Lokal Tembang Dolanan Tradisional Jawa Untuk Membentuk Karakter Anak Sejak Usia Dini (Makalah Seminar Nasional). Surakarta: Jurusan Sastra Daerah Fakultas Sastara dan Seni Rupa Universitas Sebelas Maret.

[5] Nana Syaodih Sukmadinata, 2005, Metode Penelitian Pendidikan. Bandung : PT Remaja Rosda Karya

[6] Arikunto, S. 2010:61 Prosedur Penelitiann suatu Pendekatan Praktik. Jakarta: PT Rineka Cipta.

[7] Koentjaraningrat, dkk. 1984, Kamus Istilah Antropologi. Jakarta: Pusat Pembinaan dan Pengembangan Bahasa.

[8] Edi Subroto dan Soewito, 1992. Pengantar Metode Penelitian Linguistik Struktural. Surakarta. Sebelas Maret University Press.

[9] Miles \& Huberman, A.M. 198. Qualitative Data Analysis: A Sourcebook of New Methods. Beverly Hills: Sage Publication

[10] Escarpit, Robert. (2017). Sosiologi Sastra (trans. Ida Sundari Husen). Jakarta: Yayasan Pustaka Obor Indonesia.

[11] Weedon, Chris. (2004). Identity and Culture: Narratives of Difference and Belonging. New York: Open University Press.

[12] Azyumardi Azra, Naskah dan Rekonstruksi Sejarah Sosial-Intelektual Nusantara, an article delivered in Simposium Internasional Pernaskahan Nusantara VII dan Munas Manasa III, Wisma Syahida Syarif Hidayatullah Jakarta, 26-28 Juli 2004, 2.

[13] Djajasudarma, T. Fatimah, dkk. 1977. Nilai Budaya dalam Ungkapan dan Peribahasa Sunda. Pusat Pembinaan dan Pengembangan Bahasa, Jakarta. 